\title{
Islamic Legal Maxims Analysis on Orthognathic Surgery and Treatment ${ }^{1}$
}

\author{
NOR AZURA AHMAD TARMIDZI*, WAN ABDUL FATTAH WAN ISMAIL, NALISHA \\ MOHAMED RAMLI, NADIA HALIB \& NUR AKILAH ABDUL GHAFFAR ${ }^{2}$
}

\begin{abstract}
Medical treatment by Muslim doctors will sometimes be influenced by Islamic law and ethics rather than solely medical consideration. Muslim patient's sometimes need reassurance that modern medicine that offered to them is also acceptable by Islamic law. Orthognathic deformities are condition which associated with discrepancies of the jaw. These deformities resulted from different rates of growth of the maxilla, the mandible or both. Performing cosmetic surgery seems to change the creation of Allah and the original law of changing Allah's creation is prohibited. In assessing the orthognathic surgery law for patients with this dentofacial defect, the researcher found that the main issues that need to be investigated are the difficulties existed (Masyaqqah) and the level of patient harm in addition to the intention or purpose of performing orthognathic surgery. However, according to the principles of the Islamic jurisprudence, orthognathic surgery is permitted based on the principles such as ad-darar yuzal, al-musyaqqah tajlibu al-taisir, al-darurat tuqaddiru biqadaruha, irtikab akhaf al-dhararain, al-darurat tubihu mahzurat and al-umur bimaqasidiha. Orthognathic surgery can be done because the purpose is to treat defects and restore function. This objective is very consistent with the fiqh rules that stated, every harm and distress should be eliminated.
\end{abstract}

Keywords: aesthetic surgery, dentofacial defect, facial deformities, Islamic jurisprudence, orthognathic surgery

In recent years, public interest in religious perspective on health has grown and thus making the role of religion in medical care more prominent. Religion is clearly important to many patients and it is recommended that physicians and other health care professional to understand the patient's religious background and how it affects the management of patient (Lee \& Newberg 2005). The effect of religious to patient varies, from the disease aspect and surgical outcome, behaviour and lifestyle, dealing with psychiatric problems and coping to the medical problems (Lee \& Newberg 2005).

\footnotetext{
${ }^{1}$ A version of this article has been presented at 1st IIUM International Dental Conference 2017 with its abstract published in International Medical Journal Malaysia 16(supp. 2): 26.

${ }^{2}$ Nor Azura Ahmad Tarmidzi*(corresponding author), DDS(USM), MClinDent(OMFS)(MAL), clinical lecturer at Faculty of Dentistry, Universiti Sains Islam Malaysia, Level 15, Tower B, Persiaran MPAJ, Pandan Indah, 55100 KUALA LUMPUR, Malaysia, email: azura.tarmidzi@gmail.com; Wan Abdul Fattah Wan Ismail, Ph.D., assoc. prof. at Faculty of Syariah and Law, Universiti Sains Islam Malaysia, 71800 NILAI, Negeri Sembilan, Malaysia, email: wanfattah@usim.edu.my; Nalisha Mohamed Ramli, DDS(UKM), MClinDent(OMFS)(MAL), clinical lecturer at Faculty of Dentistry, Universiti Sains Islam Malaysia, 55100 KUALA LUMPUR, Malaysia, email: nalisha@usim.edu.my; Nadia Halib, Ph.D., senior lecturer at Faculty of Dentistry, Universiti Sains Islam Malaysia, 55100 KUALA LUMPUR, Malaysia, email: nadia.halib@usim.edu.my; Nur Akilah Abdul Ghaffar, M.A., research assistant at Faculty of Syariah and Law, Universiti Sains Islam Malaysia, 71800 NILAI, Negeri Sembilan, Malaysia, email: akilahghaffar@gmail.
} 
Diversity of race and religion background among patients warrant the medical and dental practitioner to be more sensitive and able to have certain level of cultural awareness for the delivery of care (Gatrad \& Sheikh A., 2001). In Malaysia, Islam is the official religion and it is dominant in Malay culture. Medical treatment by Muslim doctors will sometimes be influenced by Islamic laws and ethics (Rispler-Chaim, 1989). Islamic ethics in general are based on foundation of Islam: The Quran, hadith and Sharia. Muslim patient sometimes seeks for reassurance that modern medicine that being offered to them is also acceptable by Islamic perspective. In view of this fact, it has opened a new aspect of research in integrating religion into health care and this is likely to develop further over the years.

Aesthetic surgery is one of the rapidly advancing areas in medical specialties. Since the early days, people have been concerned about aesthetic and appearance. Beauty has been defined by the social media nowadays as being perfectly shaped facial structures. Many people are desperately seeking for treatment to be "perfect" as displayed in the mass media. Being perfect or ideal is very subjective and it has different definition from one person to the another. Plastic surgery can be divided into two major categories which includes surgery indicated to correct congenital or acquired defects and surgery performed for beautification.

In Islam, mutilation done to the body is strictly prohibited. However, there are conditions that can cause facial deformity either congenitally or acquired. Congenital conditions include craniosynostosis, craniofacial clefts, and orthognathic deformities. Meanwhile a quired facial deformity can be the result from trauma, cyst or tumour of the jaw. Patient with dentofacial deformity may present with variety range of symptoms including speech impairment and mastication (Ryan 2012).

\section{Overview on Orthognathic Deformities and Treatment}

A person's face is a foundation for judgements about gender, ethnicity, attractiveness, emotion, and personality traits (Zebrowitz 2006). The position of facial bones contributes a great impact to the shape of the face. The bones involved in determining appearance of the face are mainly maxilla, mandible, nasal and zygomatic bone. The shape of these underlying facial bones responsible for a person's facial proportions, angles and contours. Support of the soft tissues is perhaps the most critical factor that determines aesthetic. Deficiencies of these bones may result in varying types of facial deformities.
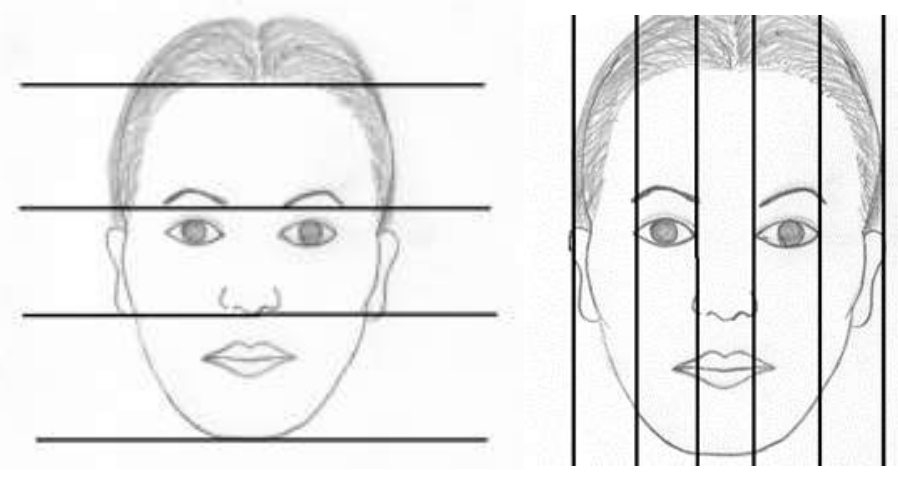

Figure 1: Equal facial proportions vertically and transversely.

Orthognathic deformities are condition associated with jaw discrepancies. These deformities resulted from different rates of growth of the maxilla, mandible or both. They may present at birth and the condition will become more apparent as the patient grows older. Examples of orthognathic deformities are facial asymmetry, mandibular hyperplasia, mandibular hypoplasia, maxillary hypoplasia, vertical maxillary deficiency and vertical maxillary excess. 
Facial deformity can result from varying degrees of discrepancy which may arise in anteroposterior, vertical and transverse plane as well as asymmetry of the face.

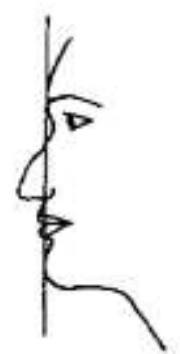

a) Class I

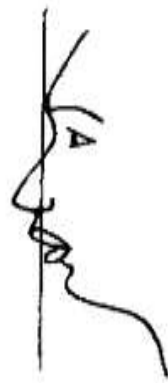

b) Class II

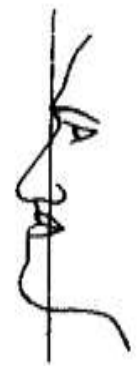

c) Class III

Figure 2: Types of facial profile

Patient with congenitally or acquired facial deformities can presented with physical and physiological abnormalities that lead to functional impairment. Functional impairments related to facial deformity include chewing and breathing problems, speech impairments as well as temporomandibular joint pathology.

The primary motivating factor for patient to correct the jaw alignment is usually bite impairment rather than appearance (Soh \& Narayanan 2013; Ngeow et. al. 2002). These problems arise due to abnormal jaw relationship which affect the structures involve in the production of mastication and speech. Breathing patterns, craniofacial growth and skeletal alteration are closely related. Obstructive sleep apnoea syndrome occurs when there is breathing impairment caused by an upper airway obstruction during sleep. This syndrome has been associated with cardiovascular disorder and is known to adversely affect life expectancy (He J., 1988). While this condition is multifactorial, a significant number of patients with obstructive sleep apnoea have underlying facial skeletal deformities.

Facial appearance is crucial to the development of normal peer relationship, healthy personal adjustment, and influence success in school and career, hence it definitely has a significant impact on social development of a person (Tobiasen 1985). Patient with facial deformity may have problems with social acceptability because people differentiate others on the basis of facial appearance. Members of the society must not judge those who were born with facial deformity but instead show them support either emotionally and financially. Psychopathology of facial deformity is a complex spectrum extending from emotional problems in the normally integrated individual to manifestations of personality disorders, neurosis, depression and psychosis.

Patients with facial deformities that causing functional impairment may require surgical intervention. Originated from the Greek word orthognathous which describes as having normally aligned jaws, orthognathic surgery is a procedure involving incision and manipulation using instrument to align the jaws into normal position between themselves and to the rest of the craniofacial complex. Historical development of orthognathic surgery started in the mid of 18th century where the first mandibular osteotomy was done (Panula 2003).

During the surgery, the bone is cut and re-aligned into the desired position. Screws and plates are used to hold the newly aligned jaw into its new position. Upon completing the surgery, patient's appearance will change not only in relation to the bony structures but can be soft tissue as well. Prior to surgical treatment, appropriate consultation to identify psychological problems should be obtained and non-surgical therapy is preferably attempted when reasonable. Studies demonstrate that orthognathic surgery will be able to improve the oral health related quality of life (Motegi \& Yamaguchi 2003). It is also proven that psychosocial function of patients who has 
undergone orthognathic surgery improved and stable between 2 and 5 years after surgery (Motegi \& Yamaguchi 2003). Demand for elective cosmetic surgery in the absence of physical disease or dysfunction continues to rise even though there is insufficient evidence to demonstrate its psychological benefits (Cook et. al. 2006).

\section{Application of Fiqh Principles in the Orthognathic Surgical Law}

Orthognathic surgery can be categorized as aesthetic or cosmetic surgical procedure. This surgery can be carried out depending on the needs and goals of treatment. Performing cosmetic surgery seems to change the creation of Allah and the original law of changing Allah's creation is prohibited. This statement refers to the word of Allah in surah an-Nisa' verse 119: "And surely, I will lead them and will fill them with vain desires, and I will command them so that they will slit the ears of the cattle, and I will command them so that they will alter the creation of Allah. And whosoever taketh Satan for a patron, instead of Allah, shall surely suffer a manifest loss".

In addition, the word of Allah in surah al-Rum verse 30: "So direct your face toward the religion, including to truth. (Adhere to) the fitrah of Allah upon which He has created (all) people. No change should there be in the creation of Allah". There is a hadith from the Prophet Muhammad PBUH to reinforce the ban on changing the creation of Allah, including cosmetic treatment: "Allah cursed the woman who does tattoos and who gets it done for herself, and those who pluck their eyebrows, and those who create spaces between their teeth artificially to look beautiful, and those who change the creation of Allah" (Narrated by Bukhari \& Muslim). However, these arguments refer to the operation of body structures that are normal and able to function. These include surgery such as nose reconstruction surgery, lips enhancer and spacing the teeth artificially.

Patients with dentofacial defect will experience some serious difficulties in carrying out normal life activities. Among the difficulties faced are mastication difficulty, respiratory problems, speaking disorder which include limitations in performing oral worships such as being unable to read the Quran fluently. Other side effect includes psychological problems involving social stigma and community acceptance. Some of them even suffer from emotional disturbances such as personality disorders, depression and psychosis.

In assessing the orthognathic surgery from Islamic perspective for patients with this dentofacial defect, we found that the main issues that need to be addressed are the difficulties existed (masyaqqah) and the level of harm caused to the patient as well as the purpose of the surgery. We will also see whether these surgeries are considered to alter the creation of Allah or vice versa. We will also relate some of the fiqh principles appropriately to answer the issues raised.

\section{Al-Masyaqqah Tajlibu Al-Taysir}

Islam is not a religion that burdens the life of its adherents with excessive hardship (Taqiuddin Al-Hosni 1997). If an order is difficult to be implemented, rukhsah or exception is available in Islam as stated in the Holy Quran, surah al-Baqarah verse 286, al-Nisa verse 28 and al-'Araf verse 157. From these arguments and research conducted by the fuqaha', thus arise the principle of: "AlMasyaqqah Tajlibu Al-Taysir" which means "difficulty in bringing convenience". This fiqh principle is based on the principle of rukhsah which eliminates the hardship Allah has imposed for some reason. This principle is also applied widely in fiqh related issues and agreed upon by Islamic scholars as one of the main or core principles (kubra).

The debate on masyaqqah (difficulty) according to Muhammad Siddiqi bin Ahmad AlBurnu (1996) is divided into two types: Masyaqqah 'adiyah and ghairu 'adiyah. Masyaqqah 'adiyah refers to difficulty that is inevitable to occur, especially in the matter of worship. Meanwhile, masyaqqah ghairu 'adiyah is divided into 3 types, which are: 
1. Masyaqqah 'azimah is defined as difficulties that exceed human capacity and causes fear of loss of life or limb. This type of masyaqqah should be given leeway to preserve the life and give priority to the limb itself. For example, there is no other way to perform hajj in Makkah but through the dangerous sea route. Thus, the necessities to to perform hajj is no longer a must for that person.

2. Masyaqqah khofifah or minor. Example of such situation is like difficulties encounter when praying while having open wound on the fingers or headache. This type of masyaqqah should not be given relief because the benefits of the worship are superior compared to the mild pain inflicted.

3. Masyaqqah mutawasitah or the moderate difficulty is between two other types of masyaqqah. For example, illness in the month of Ramadhan. If the pain will be more harmful if a person continues to fast, then he or she is obliged to break the fast. On the other hand, if the pain does not harm his/her health if he/she continues to fast, then he/she needs to continue fasting.

Therefore, if observed from the perspective of Masyaqqah, patients with dentofacial defects may experience difficulties if they did not undergo surgery such as speech, ear disease, psychological problems and others as previously stated. These problems will definitely affect patient's ability to carry a normal life like others. Depending on clinical presentation and level of dentofacial severity, masyaqqah then can be classified as 'azimah, khafifah or mutawasitah.

\section{Al-Darar Yuzal}

In assessing any problems involving the dangerous situation or distress (darurah) principles, the level of emergency should be taken into account. The appropriate principle is the principle of "aldarar yuzal" which means to eliminate harm (Ibnu Nujaym, 1983). The source of this principle is taken from the hadith of the Prophet PBUH: la dharar wa la dhirar, meaning "do not cause harm, nor respond to harm with harm" (Ibnu Majah 2015, hadith no. 2341: 353). Based on this hadith, "dharar" means causing damage or harm to others. While, "dhirar" means respond to harm with harm. Overall, this principle shows that humans are forbidden from doing harm to others either by initiating or responding to it (Ibnu Nujaym 1983). Under the core principle of al-dharurah yuzal, there are two applicable branch principles to describe orthognathic surgical law, namely $\mathrm{Al}$ Darurat Tubihu Al-Mahzurat and Al-Darurat Tuqaddaru Biqadariha.

1. Al-Darurat Tubihu al-Mahzurat: Some people are confused about the necessity of performing orthognathic surgery as they assume that this surgery is similar to cosmetic surgery, which is forbidden in Islam. First, it is important to understand that plastic surgery is divided into two types, namely cosmetic surgery and reconstructive surgery. Cosmetic surgery is a surgery performed to change the creation of Allah in order to look beautiful. For example, elevating flat nose, thickening of the lips and others. Reconstructive surgery is a plastic surgery performed for the purpose of replacing and repairing birth/acquired defects that can lead to harm or difficulties. One of the operations included under the category of reconstructive surgery is orthognathic surgery. Next, we see the prohibition of altering Allah's creation as stated in this Hadis (al-Bukhari: 4886: 6: 147):

"Allah has cursed those women who practise tattooing and those who get themselves tattooed, and those who remove their face hairs, and those who create a space between their teeth artificially to look beautiful, and such women as change the features created by Allah." 
Changing the creation of Allah is undeniably a great sin because it can lead to Allah's wrath. However, we need to understand clearly about the concept of the intended prohibition. The prohibition in the context of this hadith is the prohibition of altering the creation to look beautiful. If the surgery is done without the purpose of beauty, but with the aim of lifting the difficulty and refusing harm, then the law can change. Among the fiqh principle that is applicable in this problem is Al-Darurat Tubihu al-Mahzurat which means distress (darurah) that permit something that was previously prohibited (Al-Burnu 1997). Among the arguments that support this principle is stated in the Quran, namely surah al-An'am verse 119, al-Baqarah verse 173 and al-Maaidah verse 3 . This principle is applied if a person encounters emergency situations such as running out of food and drinks and there is only pig available during that moment. He can eat the pig just enough to sustain life. Similarly, in the case of orthognathic surgery. Initially, any surgery to change the face is prohibited, but because of the difficulty impose from the facial disharmony, the surgery becomes necessary. However, the necessity also contains its own limitations.

2. Al-Darurat Tuqaddaru Biqadariha: Undoubtedly according to medical knowledge, dentofacial defects can affect the health and life quality of the patient if not operated. According to this principle, orthognathic surgery should be performed to eliminate harm. However, every relief has its own limitations as in the same way in eliminating harm. This is based on the principle of "Al-Darurat Tuqaddaru Biqadariha" which is emergency measured according to the needs. Although Islam gives permission to do things that are prohibited during an emergency, one cannot exaggerate in applying the advantage given and facilitating the illegal issues on emergency situations (Muhammad Bakar 1996). Thus, the principle of tubihu mahzurat is bound by other rules so that the convenience and the relief provided are not misused (Mohammad Salleh 1998). This is based on the following arguments:

He has only forbidden to you dead animals, blood, the flesh of swine, and that which has been dedicated to other than Allah. But whoever is forced [by necessity], neither desiring [it] nor transgressing [its limit], there is no sin upon him. Indeed, Allah is Forgiving and Merciful (Al-Baqarah 2:173).

Although orthognathic surgery can be performed, it is only intended to eliminate harm and difficulty. Orthognathic surgery is divided into several levels and stages. However, it may vary according to the individual patient's need. Therefore, the limit of removing the harm may vary between patient depending on the professional clinical evaluation. It is permissible to do so with the intention of removing or repairing the defect only and not for the purpose of beautification. Al-Qaradawi (1993) stated: "If it turns out the person has a disability that may be disgusting to the view. For example, there is an additional meat that can cause mental and emotional pain, so it is not sinful for the person to seek treatment as long as the purpose of removing the defect or pain that can threaten his life. This is because Allah has not placed us in the religion any difficulty". Orthognathic surgery with the purpose of restoring oral function is actually included in the hajjiyat classification. Despite the status of hajiiyyat (necessity), scholars have stated that surgery should be performed with the aim of restoring the function of the oral and facial as best as possible so that the patient can function normally. The principles of Islamic jurisprudence mentioned:

$$
\text { الحاجة تنزل منزلة الضرورة عامة كانت أو خاصة }
$$


Meaning: "A wish that falls into the category of Dharurah (desperate) whether it is general or special case."

The purpose of this method is that the relief is not limited to emergency situation, but it is also in the case of hajiyyat or necessity. In other words, the relief is permissible in hajiyyat matters as permitted in emergency cases. Orthognathic surgery will improve the ability of someone to have a comprehensible speech and provide confidence in social interaction. Thus, removing a person from their difficulty and distress is recommended even though in the dentofacial deformity may not be consider as dharurah (Al-Zarqa' 1998). This statement is very relevant to the meaning of the Quran: "He never laid upon you in religion any hardship" (Al-Hajj:78).

3. Irtikab Akhaf Al-Dhararain: Orthognathic surgery is still considered as a risky surgery. No surgery is performed without any risk or effect. However, the shariah does consider the positive aspect of orthognathic surgery when it is performed to treat patients with dentofacial defects. From the medical perspective, there are so many advantages of orthognathic surgery to those with dentofacial defects. As a result, the shariah allows orthognathic surgery to ensure that the individual can live normally after surgery. Hence, if the benefit from the surgery is greater when compared to complication of orthognathic surgery itself, or the distress is more if surgery is not conducted compared to the complications of the surgery then method used is: "Irtikabu akhaffu al-dhararain" which is do the least harm of the two dangerous things".

\section{Al-Umur bi Maqasidiha}

In addition to the principle of al-Masyaqqah tajlibu al-Taisir (difficulty leading to convenience) and al-darar yuzalu (harms to be eliminated) that have been applied in orthognathic surgical law, the principle of Al-Umur bi Maqasidiha (every matter refers to the intention) is also very important to be used as a reference in determining the need for surgery in Islamic perspective. The principle of Al-Umur bi Maqasidiha (every matter refers to the intention) is based on hadith: "Actions are according to intentions, and everyone will get what was intended" (Al-Bukhari 2015, hadith no. 1: 9). Intention is the primary basis of acceptance of such practice whether it is accepted or not. If one thing is done correctly in terms of its method, but wrong in terms of its intention, then it is not accepted by Allah. Ibn Taymiyyah (1999) said:

"Indeed, intentions and beliefs are always taken into account in every action. As both are always taken into account in every worship done. The intentions that determine something is lawful or unlawful, valid or invalid, or valid from one side and invalid from another side. As the intention in worship makes it obligatory, or sunnah or lawful or unlawful, valid or invalid."

Therefore, as noted above, orthognathic surgical procedure if performed with the purpose of replacing and repairing the defective abnormality, then it is permissible according to the Islamic perspective. On the contrary, if it is done with the intention to look beautiful with purely aesthetic intention, then it became a sin due to the act of changing the creation of Allah.

Based on the Islamic jurisprudence principles of Al-darurat tubihu al-mahzurat and aldarurat tuqaddaru biqadariha, orthognathic surgery is only allowed with the purpose of eliminating difficulty/ defect/ disease. Therefore, to answer the above issues, one should refer to the principle of al-umuru bimaqasidiha (every matter refers to the intention) as well as rukhsah method (lightens the burden). Thus, if the surgery has been done and able to achieve its functional goal with visible defect, Islam still allow to make additional surgical procedure just to improve the defect. 


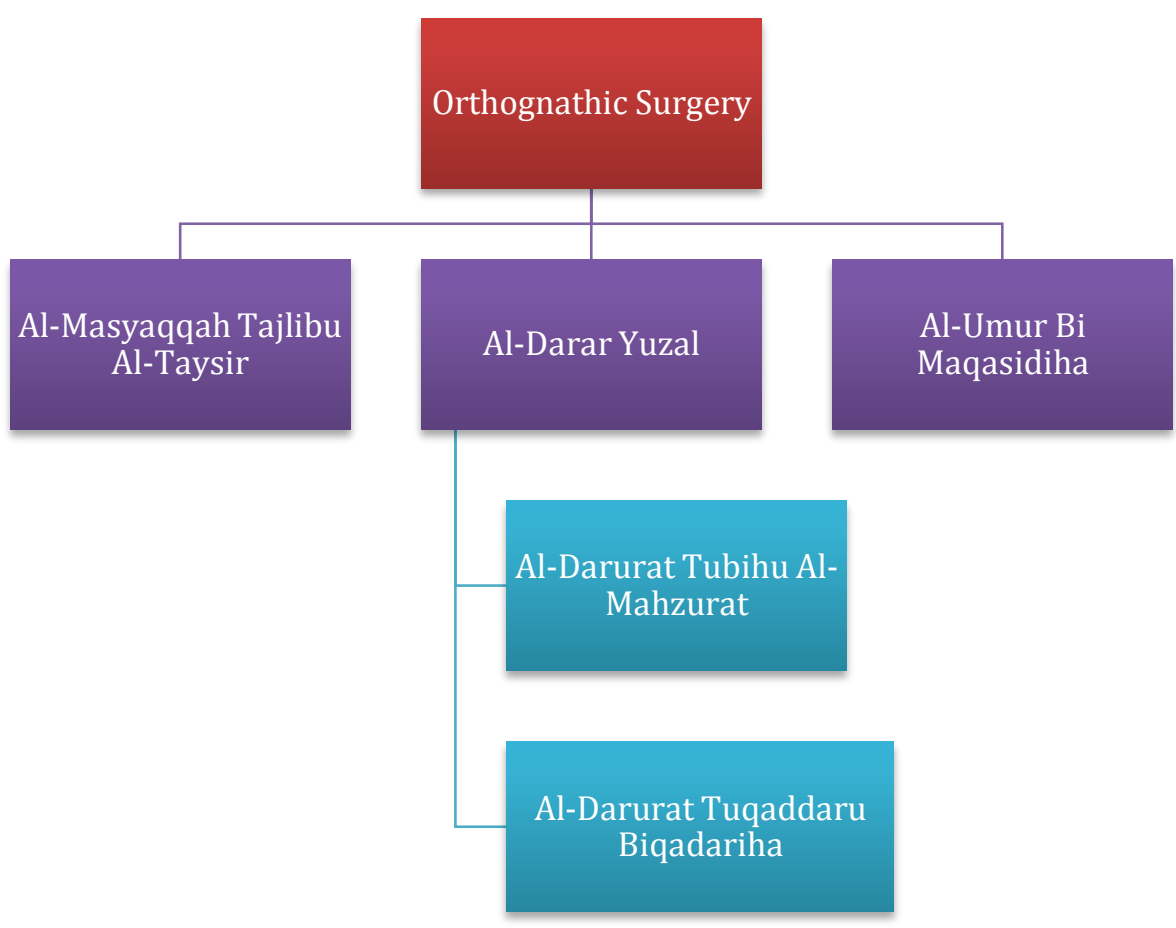

Figure 3: Orthognatic surgery and treatment, an islamic legal maxims analysis model.

In conclusion, according to the principles of the Islamic jurisprudence, orthognathic surgery is permitted based on the principles such as ad-darar yuzal, al-musyaqqah tajlibu al-taisir, al-darurat tuqaddiru biqadaruha, Irtikab Akhaf Al-Dhararain and al-darurat tubihu mahzurat serta al-Umur bimaqasidiha. Orthognathic is permitted to treat dentofacial defects and returning function as long as it is not intended solely on aesthetic baeutification. This principle coincides with the fiqh rules that have been discussed which support that every harm and distress should be eliminated. However, every case is different, and the surgery should be done according to the necessity. If the surgery is done excessively with the intent to be beautiful, then in this case it is prohibited according to the method al-darurat tuqaddiru biqadaruha and al-Umur bimaqasidiha.

The principles of this jurisprudence are governed by the authentic texts of the Qur'an and the Sunnah and are not designed to fit personal reason (Salleh Ghanim Sadhlan 1996). They are not considered to be the main arguments in the determination of the law, but these principles are important guidelines in the understanding as most of the principles were derived from the Quran, sunnah and hadith.

\section{References}

al-Bukhari, Muhammad bin Ismail al-Ja'fi. 2015. Sahih al-Bukhari. Ibn Abi Alfah, Ra'id bin Sabri (ed.). Al-Riyadh: Dar al-Hadarah li al-Nashr wa al-Tawzi.

al-Burnu, Muhammad Sidqi bin Ahmad. 1997. Mausu'ah al-Qawaid Fiqhiyyah. Riyadh: Maktabah Tawbah.

Cook, SC., Rosser, R. \& Salmon, P. 2006 Is cosmetic surgery an effective psychotherapeutic intervention? A systematic review of evidence. Journal of Plastic, Reconstructive \& Aesthetic Surgery 59: 1133-1151.

Gatrad AR, Sheikh A. 2001. Medical ethics and Islam: principles and practice. Archives of Disease in Childhood 84: 72-75.

He, J., Zorick. FJ., Conway, W, \& Roth, T. 1988. Mortality and Apnea Index in Obstructive Sleep Apnea: Experience in 385 Male Patients Chest 94: 9-14. 
Ibn Majah, Muhammad bin Yazid al-Qazwini. 2015. Sunan Ibn Majah. Ibn Abi Alfah, Ra'id bin Sabri (ed.). Al-Riyadh: Dar al-Hadarah li al-Nashr wa al-Tawzi.

Ibnu Nujaym, Zainuddin bin Ibrahim bin Muhammad Shahir. 1983. Ashbah wa Nazair. Damsyik: Dar Fikr. 94.

Ibn Taimiyyah. 1999. Al-Fatawa al-Kubra. Darul Arqam Publishing.

Lee. BY. \& Newberg, AB. 2005. Religion and health: a review and critical analysis. Zygon 40: 443468.

Motegi, E. \& Yamaguchi, H. 2003. Health-related quality of life and psychosocial function 5 years after orthognathic surgery. American Journal of Orthodontics and Dentofacial Orthopedics. 124(2): 138-143.

Mohammad Salleh Haji Ahmad. 1998. Qawaid Fiqhiyyah. Kuala Lumpur: Pustaka Haji Abdul Majid. Muhammad Bakar Ismail. 1996. Qawaid Al-Fiqhiyaah baina Ishalah wa Taujih. n.l. Dar Al-Manar.

Ngeow, WC., Ong, ST., Siow, KK \& Lian, CB. 2002. Orthognathic in the University of Malaya. Medical Journal of Malaysia 57(4): 398-403.

Panula, K. 2003. Correction of Dentofacial Deformities with Orthognathic Surgery. n.l.: Oulu University Press.

al-Qardhawi, Yusuf. 1993. Al-Halal wa al-Haram fi al-Islam. Beirut: Al-Maktab al-Islami.

Rispler-Chaim, V. 1989. Islamic medical ethics in 20th century. Journal of Medical Ethics 15: 203208.

Ryan, FS., Bernard, M \& Cunningham, SJ. 2012. Orthognathic patient's treatment expectation. American association of oral and maxillofacial surgeons. International Association of Oral and Maxillofacial Surgeon 70: 2648-2655.

Salleh Ghanim Sadhlan. 1996. Al-Qawaid al-Fiqhiyyah al-Kubra wa ma Tafarra'a 'anha. Riyadh: Dar Balansiah li al-Nashr wa Tauzi'.

Soh, CL. \& Narayanan, V. 2013. Quality of life assessment in patients with dentofacial deformity undergoing orthognathic surgery -a systemic review. International Association of Oral and Maxillofacial Surgeon 42: 974-980.

Taqiuddin al-Hosni. 1997. Kitab al-Qawaid. Riyadh: Maktabah Rushdi.

Tobiasen, JM. 1987. Social judgements of facial deformity. Cleft Palate Journal 24(4): 323-327.

al-Zarqa', Mustafa. 1998. Sharhu Qawaid Fiqhiyyah. Damascus: Dar al-Qalam.

Zebrowitz, LA. 2006. Finally, faces find favor. Social Cognition 24(5): 657-701. 